\title{
AKTIVITAS INSEKTISIDA EKSTRAK TITHONIA DIVERSIFOLIA (HEMSL.) A. GRAY (ASTERACEAE) TERHADAP ULAT DAUN KUBIS PLUTELLA XYLOSTELLA (L.) (LEPIDOPTERA: YPONOMEUTIDAE)
}

\author{
Efrin Firmansyah, Dadang, \& Ruli Anwar \\ Departemen Proteksi Tanaman, Fakultas Pertanian, Institut Pertanian Bogor \\ Jl. Kamper Kampus IPB Dramaga, Bogor 16680 \\ E-mail:mr_efrin@yahoo.com
}

\begin{abstract}
Insecticidal activity of extracts of Tithonia diversifolia (Hemsl.) A. Gray (Asteraceae) against the diamondback moth Plutella xylostella $($ L.) (Lepidoptera: Yponomeutidae). The diamondback moth, Plutella xylostella (L.) (Lepidoptera: Yponomeutidae) is one of the most destructive pests on cruciferous plants. Generally farmers use synthetic insecticides to control this pest. Intensive and excessive use of insecticides can cause some undesirable effects such as resistance, resurgence, and contamination of insecticide on environment. One effort to solve the problems caused by synthetic insecticides use is by utilization of botanical materials that are potential to be used as botanical insecticides, one of them is Tithonia diversifolia (Asteraceae). The purpose of this research was to study the insecticidal activity of $T$. diversifolia as a botanical insecticide against $P$. xylostella. The leaf residual and topical application methods were used to assess the mortality effect of the extracts. Insect mortality rate was analyzed using probit analysis to obtain $\mathrm{LC}_{50}$ and $\mathrm{LC}_{95}$ values. The results showed that the flower extract had better activity on insect mortality than the leaf extract both in leaf residual and topical application treatments.
\end{abstract}

Key words: Botanical insecticides, environmentally friendly, mortality

\begin{abstract}
ABSTRAK
Aktivitas insektisida ekstrak Tithonia diversifolia(Hemsl.) A. Gray (Asteraceae) terhadap ulat daun kubis Plutella xylostella (L.) (Lepidoptera: Yponomeutidae). Ulat daun kubis Plutella xylostella (L.) (Lepidoptera: Yponomeutidae) merupakan salah satu hama yang merusak tanaman kubis-kubisan. Untuk mengendalikan hama tersebut petani umumnya menggunakan insektisida sintetik yang jika penggunaannya terus-menerus dapat menyebabkan resistensi, meningkatnya residu serta berpengaruh pada kesehatan lingkungan. Salah satu upaya yang dapat dilakukan untuk menyikapi masalah akibat penggunaan pestisida sintetik adalah dengan memanfaatkan bahan alami yang berpotensi untuk digunakan sebagai bahan baku insektisida nabati yang salah satunya adalah Tithonia diversifolia (Asteraceae). Tujuan penelitian ini mempelajari aktivitas insektisida ekstrak metanol daun dan bunga $T$. diversifolia terhadap ulat daun kubis $P$. xylostella. Dua metode uji digunakan untuk menilai pengaruh ekstrak $T$. diversifolia terhadap mortalitas larva $P$. xylostella yaitu metode residu pada daun dan metode aplikasi topikal. Tingkat mortalitas serangga diolah dengan menggunakan analisis probit untuk mendapatkan nilai $\mathrm{LC}_{50} \mathrm{dan}_{\mathrm{LC}} \mathrm{C}_{95}$ dari masing-masing ekstrak. Hasil penelitian menunjukkan bahwa ekstrak bunga T. diversifolia memiliki efek mortalitas lebih tinggi terhadap P. xylostella daripada ekstrak daun baik pada perlakuan dengan metode residu pada daun maupun aplikasi topikal.
\end{abstract}

Kata kunci: insektisida nabati, mortalitas, ramah lingkungan

\section{PENDAHULUAN}

Tanaman kubis-kubisan (Brassicaceae) seperti sawi, kol kembang, brokoli, dan kubis merupakan jenis tanaman sayuran yang banyak dibudidayakan oleh petani Indonesia. Secara umum selama periode 2011-2015 produksi tanaman kubis-kubisan mengalami fluktuasi (BPS, 2015). Beberapa faktor yang berkontribusi dalam penurunan produksi tanaman di antaranya adalah penurunan kesuburan lahan, berkurangnya lahan produksi, dan adanya serangan organisme pengganggu tanaman. Ulat daun kubis Plutella xylostella (L.) (Lepidoptera: Yponomeutidae) merupakan salah satu hama yang menyerang tanaman kubis-kubisan (Brassicaceae) di seluruh dunia (Sarfraz \& Kaddie, 2005). Kerusakan tanaman disebabkan oleh aktivitas 
makan larva yang pada populasi tinggi dapat merusak tanaman secara berat kecuali pada bagian batangnya (Capinera, 2001).

Pengendalian secara kimia dengan insektisida sintetik merupakan teknik pengendalian yang paling umum dilakukan untuk mengendalikan $P$. xylostella di seluruh dunia (Syed et al., 2004). Penggunaan insektisida sintetik selain efektif namun jika penggunaannya secara terus menerus dapat menyebabkan resistensi (Kau \& Cheng, 2001). Kejadian resistensi hama $P$. xylostella terhadap insektisida pertama kali dilaporkan oleh Ankersmit (1953) yaitu resistensi hama terhadap DDT di Indonesia. Selain resistensi, penggunaan insektisida sintetik yang terus menerus secara tidak bijaksana juga berpengaruh pada kesehatan lingkungan serta residu pada produk pertanian yang menimbulkan bahaya pada konsumen (Dadang \& Prijono, 2008).

Salah satu upaya yang dapat dilakukan untuk meminimalisasi masalah akibat penggunaan pestisida sintetik adalah dengan mencari alternatif bahan alami untuk menggantikan penggunaan insektisida sintetik yang banyak menimbulkan masalah lingkungan. Secara umum insektisida nabati diartikan sebagai suatu insektisida yang bahan dasarnya adalah senyawa tumbuhan yang bersifat mudah terurai di alam (Mkenda et al., 2014), relatif aman terhadap organisme bukan sasaran termasuk musuh alami, dapat dipadukan dengan komponen lain pengendalian hama terpadu dan dapat memperlambat laju resistensi (Dadang \& Prijono, 2008). Berdasarkan hal tersebut penggunaan insektisida nabati diharapkan mampu mengurangi atau bahkan menggantikan penggunaan pestisida sintetik di lapangan dan menjadi bahan pengendali yang ramah lingkungan, aman, dan sehat (Djunaedy, 2009).

Tithonia diversifolia (Asteraceae) yang merupakan tumbuhan liar dan berpotensi menjadi gulma pada areal pertanian, belum banyak dimanfaatkan oleh petani-petani di Indonesia. Biasanya masyarakat memanfaatkan tumbuhan ini sebagai pakan ternak ruminansia. Pemanfaatan lainnya adalah sebagai pupuk organik (Pardono, 2011). Di luar negeri T. diversifolia selain dimanfaatkan sebagai pakan ternak dan bahan pupuk organik, juga dimanfaatkan sebagai bahan baku insektisida nabati. $T$. diversifolia mengandung senyawa-senyawa yang bersifat toksik terhadap serangga seperti flavonoid, tanin, dan triterpena yang berpotensi dapat dijadikan sebagai insektisida nabati untuk mengendalikan Atta cephalotes (Hymenoptera: Myrmicinae) (Castano-Quintana et al., 2013) dan larva Chlosyne lacinia (Lepidoptera: Nymphalidae) (Ambrosio et al., 2008). Hasil penelitian Carino \&
Morallo-Rejesus (1982) menunjukkan tingkat toksik ekstrak daun $T$. diversifolia terhadap $P$. xylostella $24,47 \%$ lebih rendah dibandingkan dengan insektisida sintetik malathion, namun ekstrak tersebut lebih baik jika dibandingkan dengan tingkat toksiknya pada empat serangga lain (Dysdercus cingulatus Fab, Tribolium castaneum Herbsr, Sitophilus zeamais Motsch, dan Spodoptera exempta Walker). Di Indonesia, pemanfaatan $T$. diversifolia hanya sebagai pakan ternak dan pupuk organik dan belum banyak dipelajari potensinya sebagai pengendali hama tanaman atau insektisida khususnya untuk mengendalikan ulat daun kubis $P$. xylostella. Oleh karena itu tujuan dari penelitian ini untuk mengetahui aktivitas insektisida ekstrak metanol daun dan bunga $T$. diversifolia terhadap larva $P$. xylostella.

\section{METODE PENELITIAN}

Tempat dan Waktu. Penelitian dilaksanakan di Laboratorium Fisiologi dan Toksikologi Serangga, Departemen Proteksi Tanaman, Institut Pertanian Bogor dengan suhu rata-rata $26,6^{\circ} \mathrm{C}$ dan rata-rata kelembapan 67,5\% dari September 2015 sampai Mei 2016.

Penanaman dan Pemeliharaan Brokoli. Tanaman brokoli (Brassica oleraceae L. var. italica) yang digunakan sebagai media untuk menguji pengaruh ekstrak $T$. diversifolia terhadap larva $P$. xyostella ditanam di lahan dengan menggunakan polybag. Benih brokoli disemai pada wadah penyemaian yang berisi tanah dan pupuk kandang 2:1 (v/v) yang telah dicampur rata. Setelah berumur 3 minggu, sebanyak satu bibit ditanam pada polybag berukuran besar (5 liter) yang telah berisi campuran tanah dan pupuk kandang 2:1 (v/ v). Pemupukan tambahan dilakukan ketika tanaman berumur 3-4 minggu melalui pemberian pupuk NPK dengan dosis $1 \mathrm{~g} /$ tanaman. Pemeliharaan tanaman brokoli meliputi penyiraman yang dilakukan dua kali sehari, penyulaman terhadap tanaman yang mati, penyiangan gulma, dan pengendalian hama dilakukan secara mekanis. Daun dari tanaman berumur 2 bulan atau lebih digunakan sebagai pakan larva $P$. xylostella.

Pemeliharaan dan Perbanyakan Serangga Uji. Serangga yang digunakan sebagai hama sasaran adalah larva $P$. xylostella instar III generasi kedua berdasarkan pemeliharaan di laboratorium. Imago serangga didapatkan dari daerah Cipanas, Cianjur (6 $6^{\circ} 44^{\prime} 58.81^{\prime \prime}$ LS dan $107^{\circ} 1$ '17.47" BT) yang dikumpulkan dan dipelihara di laboratorium dengan cara dimasukkan ke dalam kurungan kasa tempat pemeliharan $(50$ × 50 × 50 
$\mathrm{cm}$ ). Imago tersebut diberi pakan larutan madu 10\% (v/ v) yang diserapkan pada kapas yang digantungkan di tengah-tengah kurungan menggunakan seutas benang. Pada bagian dasar kurungan diletakkan daun brokoli pada pot kecil berisi air sebagai tempat peletakan telur. Daun yang telah diletaki telur dipindahkan ke dalam kotak plastik $(30 \times 25 \times 7 \mathrm{~cm})$ tempat pemeliharaan. Telur-telur tersebut dipelihara hingga menetas kemudian setelah menjadi larva, serangga diberi makan daun brokoli bebas pestisida.

Ekstraksi Tumbuhan. Metode yang digunakan untuk mendapatkan ekstrak $T$. diversifolia adalah metode maserasi (Dadang \& Prijono, 2011). Tanaman diperoleh dari kebun pertanian organik di daerah Cisarua Bogor (641'20.30" LS dan 10656'55.63 BT). Bagian tanaman yang digunakan sebagai bahan pembuatan ekstrak adalah bagian daun dan bunga. Setiap bahan tersebut dipotong menjadi bagian-bagian kecil kemudian dikeringanginkan selama 7 hari di laboratorium, lalu dihaluskan menggunakan blender secara terpisah hingga menjadi serbuk. Serbuk yang terbentuk diayak menggunakan pengayak kasa berjalinan $1 \mathrm{~mm}$. Setiap serbuk yang telah dihasilkan direndam dalam pelarut metanol sebanyak dua kali dengan perbandingan 1:10 (w/v) selama 48 jam. Rendaman kemudian disaring menggunakan corong Buchner yang dialasi kertas saring Whatman. Hasil saringan kemudian diuapkan menggunakan rotary evaporator pada suhu $50{ }^{\circ} \mathrm{C}$ dan tekanan 240 mbar sehingga diperoleh ekstrak kasar. Ekstrak yang diperoleh disimpan dalam lemari es $\left(4{ }^{\circ} \mathrm{C}\right)$ hingga saat digunakan.

\section{Uji Toksisitas Ekstrak terhadap Larva} P. xylostella. Setiap ekstrak diuji pada lima taraf konsentrasi yang diharapkan dapat mengakibatkan kematian serangga uji 5\% hingga 95\%, yang ditentukan dengan uji pendahuluan. Konsentrasi ekstrak yang digunakan untuk uji pendahuluan adalah $5 \%, 3 \%, 1 \%$, $0,5 \%$, dan $0,1 \%$. Setelah diperoleh data mortalitas hasil uji pendahuluan kemudian dilakukan analisis probit untuk memperoleh konsentrasi yang akan digunakan pada uji lanjutan. Konsentrasi uji lanjut ekstrak metanol daun $T$. diversifolia berturut-turut $0,02 \%, 0,04 \%, 0,09 \%, 0,22 \%$, dan $0,97 \%$ serta untuk ekstrak bunga berturut-turut $0,01 \%, 0,04 \%, 0,08 \%, 0,19 \%$, dan 0,86\%. Pembuatan konsentrasi larutan ekstrak dilakukan dengan metode pengenceran berseri (serial dilution). Setiap larutan ekstrak mengandung metanol sebanyak $1 \%$ dan Tween$800,2 \%$. Pengujian toksisitas dilakukan dengan dua metode yaitu metode residu pada daun dan metode aplikasi topikal.
Metode residu pada daun. Potongan daun brokoli (4 $\mathrm{cm}$ x $4 \mathrm{~cm}$ ) dicelupkan ke dalam sediaan ekstrak pada konsentrasi tertentu kemudian dikeringanginkan. Daun kontrol dicelupkan ke dalam $100 \mathrm{ml}$ larutan air yang mengandung 1,2\% metanol dan Tween 80 (5:1, v/v) (Dadang \& Prijono, 2008). Sebanyak dua lembar daun dimasukkan ke dalam cawan petri (diameter $9 \mathrm{~cm}$ ), lalu dimasukkan 10 larva $P$. xylostella instar III. Setiap perlakuan dan kontrol diulang lima kali. Daun perlakuan dan kontrol diganti setiap 24 jam setelah perlakuan dengan daun tanpa perlakuan. Pengamatan mortalitas larva dilakukan setiap 24 jam selama 6 hari. Persentase kematian untuk setiap konsentrasi ekstrak dianalisis dengan program analisis probit POLO-PC untuk menentukan hubungan konsentrasi/dosis dengan kematian serangga uji (Finney, 1971).

Metode aplikasi topikal. Sebanyak 10 larva $P$. xylostella instar III dimasukkan ke dalam cawan petri (diameter $9 \mathrm{~cm}$ ) yang telah dialasi tisu. Larva ditetesi 1 $\mu l$ larutan ekstrak pada masing-masing perlakuan atau kontrol yang mengandung air, metanol (1\%) dan Tween $80(0,2 \%)$ pada bagian dorsal toraks menggunakan microapplicator. Setelah tetesan kering, dua lembar daun brokoli $(4 \times 4 \mathrm{~cm})$ tanpa perlakuan diberikan sebagai pakan. Setiap perlakuan dan kontrol diulang sebanyak lima kali. Pengamatan dilakukan setiap 24 jam selama 6 hari dengan menghitung jumlah larva yang mati.

Analisis Data. Data mortalitas ditabulasi pada program komputer Microsoft Excel 2007 kemudian dianalisis probit menggunakan program POLO-PC (LeOra Software, 1987) untuk mendapatkan $\mathrm{LC}_{50}$ dan $\mathrm{LC}_{95}$.

\section{HASIL DAN PEMBAHASAN}

Larva $P$. xylostella pada perlakuan ekstrak daun T. diversifolia dengan metode residu pada daun mulai mengalami kematian pada 48 jam setelah perlakuan (JSP) sampai 144 JSP kecuali pada perlakuan $0,02 \%$ dan $0,04 \%$, kematian larva mulai terjadi pada 72 JSP. Pengamatan 96 JSP menunjukkan kematian larva kurang dari $50 \%$ pada semua perlakuan. Persentase kematian tertinggi dan terendah yaitu masing-masing sebesar $48 \%$ dan $10 \%$ terjadi pada perlakuan dengan konsentrasi $0,97 \%$ dan $0,02 \%$. Pengamatan 144 JSP menunjukkan mortalitas larva $94 \%, 86 \%, 72 \%, 32 \%$, dan $18 \%$ pada konsentrasi berturut-turut $0,97 \%, 0,22 \%, 0,09 \%, 0,04 \%$, dan 0,02\% (Gambar 1A).

Perkembangan mortalitas larva $P$. xylostella pada perlakuan ekstrak bunga $T$. diversifolia dengan 
metode residu pada daun menunjukkan kematian larva dimulai sejak 24 JSP sampai 144 JSP kecuali pada perlakuan $0,01 \%$, kematian larva mulai terjadi pada 48 JSP. Pengamatan 96 JSP menunjukkan kematian larva mencapai $50 \%$ pada konsentrasi $0,86 \%$ dan $26 \%$ pada konsentrasi $0,01 \%$. Pengamatan 144 JSP menunjukkan mortalitas larva mencapai $98 \%, 84 \%, 76 \%, 66 \%$, dan $44 \%$ pada konsentrasi berturut-turut $0,86 \%, 0,19 \%$, 0,08\%, 0,04\%, dan 0,01\% (Gambar 1B).

Kematian larva $P$. xylostella pada perlakuan ekstrak daun $T$. diversifolia dengan metode aplikasi topikal terjadi sejak 24 JSP sampai 144 JSP. Peningkatan kematian terjadi pada setiap waktu pengamatan dan peningkatan yang tinggi terjadi pada pengamatan 96 JSP, yang menunjukkan mortalitas mencapai $80 \%, 76 \%, 60 \%$, $52 \%$, dan $42 \%$ pada dosis berturut-turut 9,7, 2,2, 0,9, 0,4 , dan $0,2 \mathrm{mg} / \mathrm{larva}$. Pengamatan pada $144 \mathrm{JSP}$ menunjukkan kematian larva mencapai berturut-turut $96 \%, 88 \%, 80 \%, 70 \%$, dan $46 \%$ pada perlakuan dengan kelima dosis tersebut (Gambar 2A).

Perkembangan mortalitas larva $P$. xylostella pada perlakuan ekstrak bunga $T$. diversifolia dengan metode aplikasi topikal menunjukkan kematian larva mencapai $46 \%$ pada dosis $8,6 \mathrm{mg} /$ larva pada pengamatan $24 \mathrm{JSP}$. Perkembangan mortalitas pada perlakuan ini relatif lebih cepat daripada perlakuan dengan metode residu pada
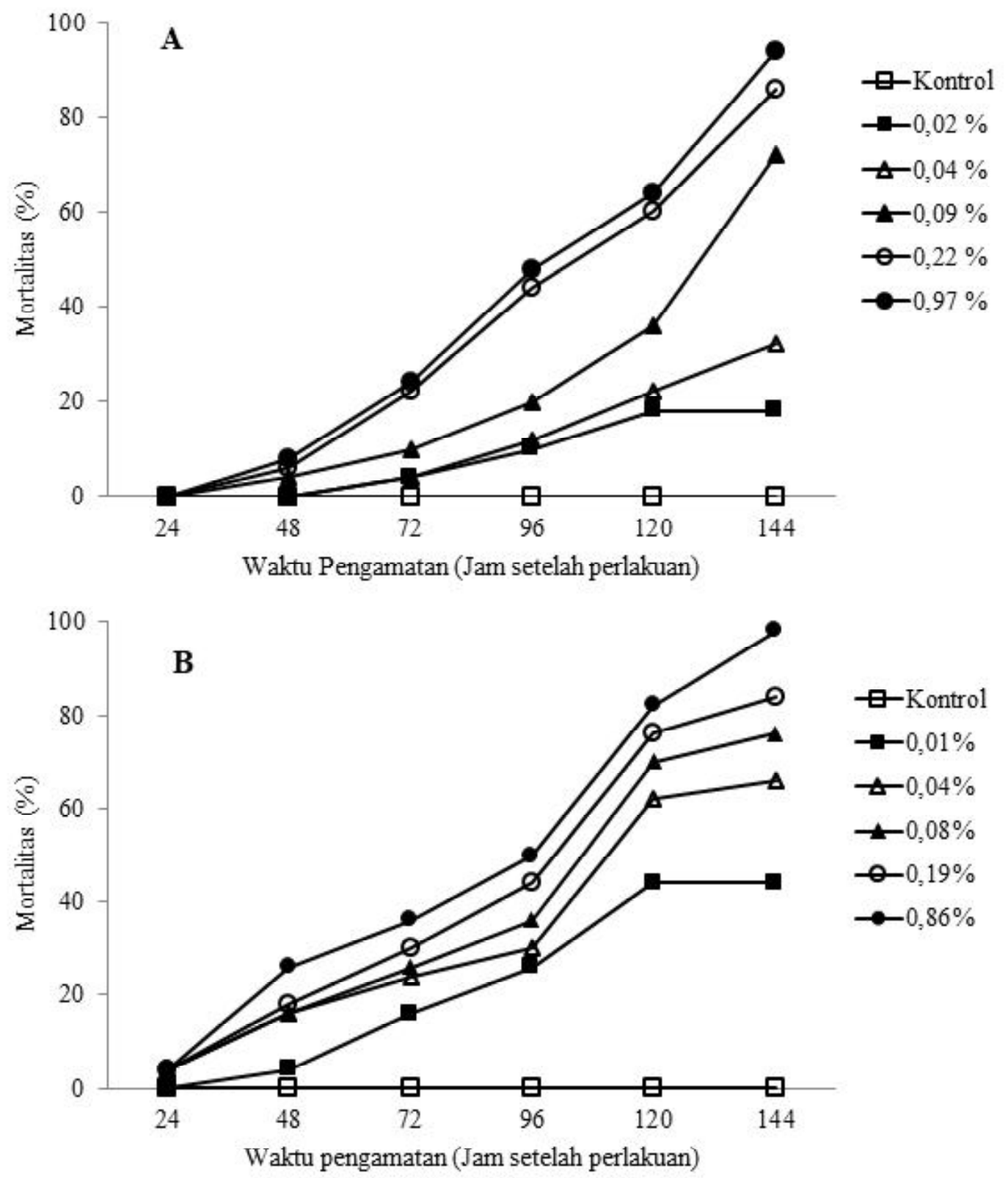

Gambar 1. Perkembangan mortalitas larva P. xylostella pada perlakuan ekstrak daun (A) dan bunga (B) $T$. diversifolia dengan metode residu pada daun. 
daun baik dengan metode residu pada daun maupun metode aplikasi topikal. Pada 96 JSP kematian mencapai $100 \%, 92 \%, 76 \%, 76 \%$ dan $50 \%$ pada dosis berturutturut $8,6,1,9,0,8,0,4$, dan $0,1 \mathrm{mg} /$ larva. Pengamatan pada 144 JSP menunjukkan kematian larva mencapai berturut-turut $100 \%, 98 \%, 90 \%, 84 \%$, dan $72 \%$ pada perlakuan dengan kelima dosis tersebut (Gambar 2B).

Berdasarkan analisis probit, ekstrak bunga lebih toksik daripada ekstrak daun baik pada metode residu pada daun maupun metode aplikasi topikal. Melalui metode residu pada daun $\mathrm{LC}_{50}$ dan $\mathrm{LC}_{95}$ berturut-turut $0,06 \%$ dan $0,64 \%$ untuk ekstrak daun serta $0,02 \%$ dan $0,56 \%$ untuk ekstrak bunga. Sementara itu $\mathrm{LD}_{50}$ dan
$\mathrm{LD}_{95}$ ekstrak bunga yang diaplikasikan dengan metode aplikasi topikal berturut-turut sebesar 0,04 dan 1,32 mg/ larva yang lebih rendah daripada $\mathrm{LD}_{50}$ dan $\mathrm{LD}_{95}$ ekstrak daun yang berturut-turut 0,17 dan 5,14 mg/larva (Tabel $1)$.

Hasil penelitian ini menunjukkan terdapat pengaruh pemberian ekstrak daun dan bunga $T$. diversifolia terhadap mortalitas larva P. xylostella. Hal ini membuktikan bahwa tumbuhan $T$. diversifolia berpotensi untuk dijadikan sebagai insektisida nabati (Isman, 2014). Beberapa penelitian lain yang menunjukkan potensi tersebut di antaranya adalah Rusli et al. (2010) yang melaporkan bahwa $T$. diversifolia
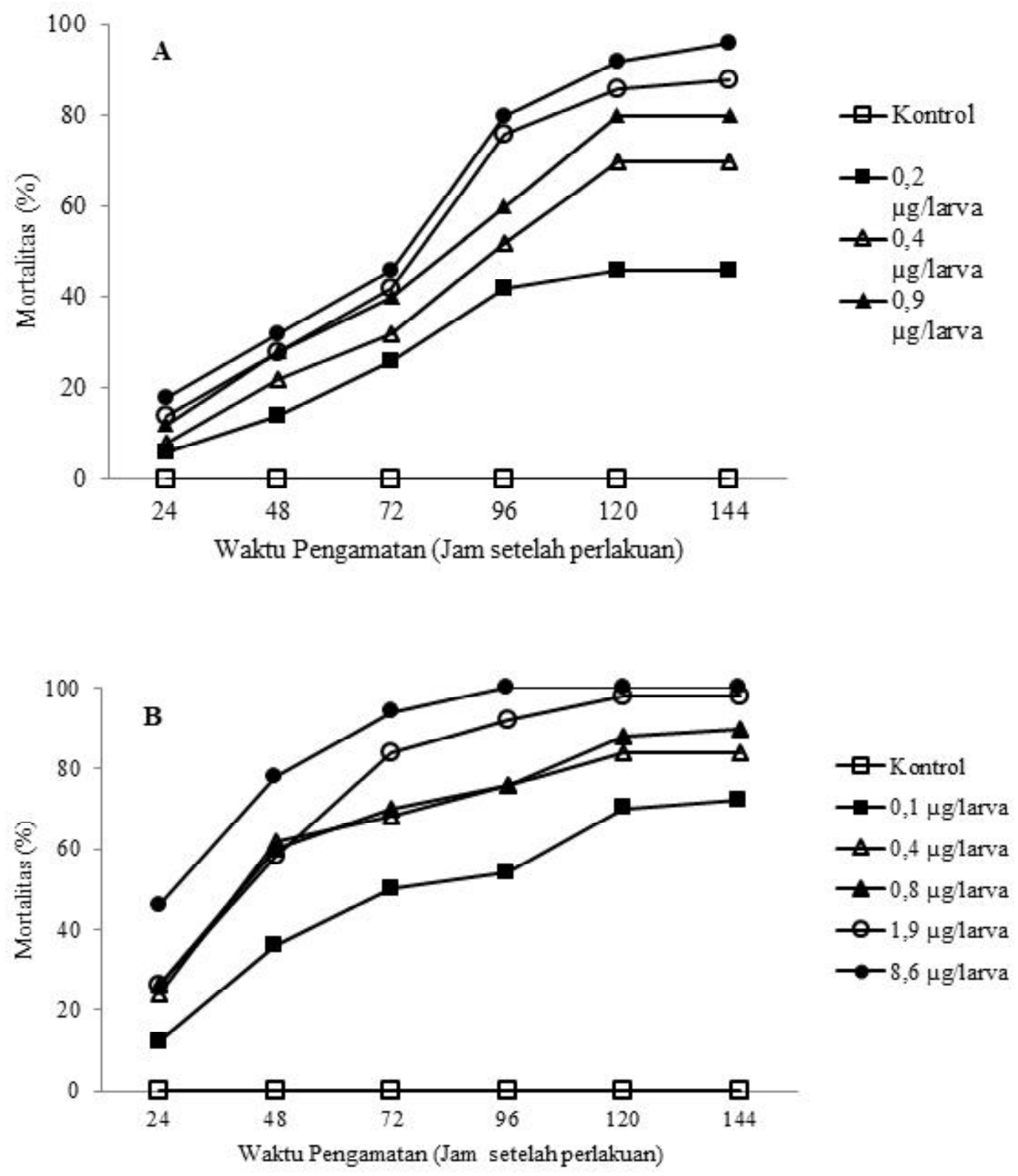

Gambar 2. Perkembangan mortalitas larva P. xylostella pada perlakuan ekstrak daun (A) dan bunga (B) $T$. diversifolia dengan metode aplikasi topikal. 
Tabel 1. Penduga parameter regresi probit hubungan antara konsentrasi atau dosis ekstrak T. diversifolia dengan mortalitas larva P. xylostella pada 144 JSP

\begin{tabular}{ccccc}
\hline Perlakuan $^{\mathrm{a}}$ & $a^{\mathrm{b}} \pm \mathrm{GB}$ & $b^{\mathrm{c}} \pm \mathrm{GB}^{\mathrm{d}}$ & $\mathrm{LC}_{50}{ }^{\mathrm{e}}\left(\mathrm{SK}^{\mathrm{f}} 95 \%\right)(\%)$ & $\mathrm{LC}_{95}(\mathrm{SK} 95 \%)(\%)$ \\
\hline $\mathrm{DR}$ & $1,95 \pm 0,23$ & $1,57 \pm 0,19$ & $0,06(0,023-0,114)$ & $0,64(0,252-11,213)$ \\
$\mathrm{BR}$ & $1,92 \pm 0,24$ & $1,09 \pm 0,18$ & $0,02(0,010-0,031)$ & $0,56(0,291-1,87)$ \\
\hline & & $\mathrm{LD}_{50}{ }^{\mathrm{g}}(\mathrm{SK} 95 \%)$ & $\mathrm{LD}_{95}(\mathrm{SK} 95 \%)$ \\
& & & $(\mu \mathrm{g} / \mathrm{larva})$ & $6,02(3,07-21,07)$ \\
\hline DT & $0,83 \pm 0,10$ & $1,04 \pm 0,18$ & $0,16(0,07-0,27)$ & $1,32(0,72-6,65)$ \\
BT & $1,56 \pm 0,16$ & $1,17 \pm 0,26$ & $0,04(0,015-0,095)$ &
\end{tabular}

${ }^{\mathrm{a}} \mathrm{DR}=$ ekstrak daun dengan metode residu pada daun, $\mathrm{BR}=$ ekstrak metanol bunga dengan metode residu pada daun, DT $=$ ekstrak daun dengan metode aplikasi topikal. $\mathrm{BT}=$ ekstrak bunga dengan metode aplikasi topikal. ${ }^{\mathrm{b}} \mathrm{a}=$ intersep garis regresi probit, ${ }^{\mathrm{c}} \mathrm{b}=$ kemiringan regresi probit, ${ }^{\mathrm{d}} \mathrm{GB}$ : galat baku. ${ }^{\mathrm{e}} \mathrm{LC}$ : lethal concentration, ${ }^{\mathrm{f}} \mathrm{SK}$ : selang kepercayaan, ${ }^{\mathrm{g}} \mathrm{LD}=$ lethal dose.

dapat digunakan sebagai insektisida untuk mengendalikan Spodoptera exigua. Ekstrak daun T. diversifolia dilaporkan berpotensi untuk dijadikan sebagai insektisida nabati untuk mengendalikan hama gudang Callosobruchus maculatus (Coleoptera: Bruchidae) (Adedire \& Akinneye, 2004; Kolawole et al., 2014), larva nyamuk Aedes aegypti (Bernard et al., 2012), larva Chrysomya bezziana (Wardhana \& Diana 2014), Macrotermes bellicosus (Oyedokun et al. 2011) dan Macrotermes spp. (Osipitan \& Oseyemi, 2012). Tithonia diversifolia juga dapat dimanfaatkan untuk mengendalikan Sitophilus zeamais (Onekutu et al., 2015) dan Atta cephalotes (Hymenoptera: Formicidae) (Zanetti et al., 2014, Rodriguez et al., 2015).

Tithonia diversifolia diketahui mengandung beberapa senyawa metabolit sekunder diantaranya seskuiterpena, diterpena, monoterpena, dan kandungan alisiklik yang bersifat toksik yang berasal dari bagian daun, batang, atau bunga (Mkenda et al., 2014; Mkenda \& Ndakidemi, 2014). Tanaman ini juga diketahui mengandung senyawa glikosida, tanin, flavonoid, saponin, fenol, dan alkaloid (Otusanya \& Ilori, 2012). Beberapa senyawa golongan sesquiterpen yang terdapat pada $T$. diversifolia adalah germakren sesquiterpena (1asetiltagitinin-A) dan guanianana sesquiterpena ( $8 \boldsymbol{\beta}$ isobutiliriloksikumambranolida) (Kuo \& Chen, 1998).

Hasil penelitian menunjukkan perlakuan ekstrak bunga dengan metode aplikasi topikal lebih toksik daripada ekstrak daun dengan metode aplikasi topikal dan metode residu pada daun. Hasil tersebut sejalan dengan penelitian Mukasa et al. (2008) yang menunjukkan bahwa ekstrak bunga $T$. diversifolia lebih toksik daripada ekstrak daun terhadap Cosmopolites sordidus (Germar) (Coleoptera: Curculionidae). Fouad et al. (2014) menyatakan ekstrak bunga $T$. diversifolia dengan metode aplikasi topikal menjadi salah satu bahan alami yang berpotensi dijadikan sebagai insektisida nabati untuk mengendalikan hama Sitotroga cereallea (Lepidoptera: Gelechiidae). Hasil penelitian Carino \& Morallo-Rejesus (1982) menunjukkan aplikasi topikal pada serangga uji yang memiliki tekstur kutikula halus seperti larva $P$. xylostella akan meningkatkan tingkat toksik ekstrak $T$. diversifolia yang diaplikasikan karena penetrasi senyawa kimia pada kutikula serangga tersebut terjadi lebih efisien.

Ekstrak bunga $T$. diversifolia mengandung senyawa fenol, tanin dan flavonoid (da Gama et al., 2014). Menurut Utami et al. (2010) senyawa fenol dapat berperan sebagai perangsang aktivitas makan yang mengakibatkan serangga uji mati karena banyak memakan senyawa toksik pada daun perlakuan (daun caisim). Hasil penelitian Mwanauta et al. (2014) menunjukkan beberapa senyawa monoterpena yang terkandung dalam $T$. diversifolia yaitu b-osimena, apinena, dan limonena. Menurut Ibrahim et al. (2001) senyawa monoterpena (limonene) bersifat toksik yang masuk melalui lapisan kutikula (racun kontak), saluran pernapasan dan saluran pencernaan (racun perut) dapat mengakibatkan kematian serangga. Adapun seskuiterpena dan flavonoid mampu masuk ke dalam membran lipid bilayer yang mengakibatkan fluiditas membran dan permeabilitas sel otot meningkat. Kondisi ini akan melemahkan gerakan serangga dan berakhir dengan kematian (Cestari et al., 2004). Perbedaan tingkat mortalitas yang ditimbulkan masing-masing perlakuan dapat diakibatkan oleh adanya perbedaan karakteristik dari senyawa metabolit sekunder yang terkandung di dalam masing-masing ekstrak termasuk perbedaan dari cara kerja senyawa tersebut (War et al., 2013). 


\section{SIMPULAN}

Secara umum baik ekstrak daun maupun ekstrak bunga $T$. diversifolia mengakibatkan kematian larva $P$. xylostella. Ekstrak bunga $T$. diversifolia dengan metode aplikasi topikal memilliki aktivitas mortalitas lebih tinggi dari pada ekstrak daun terhadap larva P. xylostella baik pada perlakuan dengan metode residu pada daun maupun aplikasi topikal.

\section{SANWACANA}

Penulis mengucapkan terima kasih kepada Lembaga Pengelola Dana Keuangan (LPDP) Kementerian Keuangan RI atas dukungan seluruh pendanaan penelitian. Penulis juga mengucapkan terima kasih kepada Ir. Djoko Prijono, MAgr.Sc. sebagai sebagai Kepala Laboratorium Fisiologi dan Toksikologi Serangga, Departemen Proteksi Tanaman, Institut Pertanian Bogor.

\section{DAFTAR PUSTAKA}

Adedire CO \& Akinneye JO. 2004. Biological activity of tree marigold, Tithonia diversifolia, on cowpea seed bruchid, Callosobruchus maculatus (Coleoptera: Bruchidae). Ann. Appl. Biol. 144(2): 185-189.

Ambrósio SR, Oki Y, Heleno VCG, Chaves JS, Nascimento PGBD, Lichston JE, Constantino MG, Varanda EM, \& Da Costa FB. 2008. Constituents of glandular trichomes of Tithonia diversifolia: relationships to herbivory and antifeedant activity. Phytochemistry 69(10): 2052-2060.

Ankersmit GW. 1953. DDT-resistance in Plutella maculipennis (Curt.) (Lep.) in Java. Bull. Entomol. Res. 44(3): 421-425.

Bernard KL, David SK, Mark NO, Charles MK, Geoffrey RM, Charles M, Laban I, \& Willy TK. 2012. Larvicidal action of extracts from Tithonia diversifolia against the dengue mosquito Aedes aegypti (Diptera: Culicidae). JBAPN 2(1): 4649.

[BPS] Badan Pusat Statistik. 2015. Produksi sayuran di Indonesia, 2011-2015.http:// pertanian.go.id/ D a t a $5 \mathrm{tahun} / \mathrm{H}$ orti A S EM $2015 / 3$ Produksi\%20Nasional\%20Sayuran.pdf. Diakses tanggal 16 Mei 2016.
Capinera JL. 2001. Handbook of Vegetable Pests. Academic Press. San Diego.

Carino FA \& Morallo-Rejesus B. 1982. Isolation and characterization of the insecticidal fraction from Tithonia diversifolia (A. Gray) leaves. Annals Trop. Res. 4(1): 1-11.

Castańo-Quintana K , Montoya-Lerma J, \& GiraldoEcheverri C. 2013. Toxicity of foliage extracts of Tithonia diversifolia (Asteraceae) on Atta cephalotes (Hymenoptera: Myrmicinae) workers. Ind. Crops Prod. 44: 391-395.

Cestari IM, Sarti SJ, Waib CM, \& Branco Jr AC. 2004. Evaluation of the potential insecticide activity of Tagetes minuta (Asteraceae) essential oil against the head lice Pediculus humanus capitis (Phthiraptera: Pediculidae). Neotrop. Entomol. 33(6): 805-807.

Dadang \& Prijono D. 2008. Insektisida Nabati: Prinsip, Pemanfaatan dan Pengembangan. Departemen Proteksi Tanaman, Fakultas Pertanian, Institut Pertanian Bogor.

Dadang \& Prijono D. 2011. Pengembangan teknologi formulasi insektisida nabati untuk pengendalian hama sayuran dalam upaya menghasilkan produk sayuran sehat. JIPI 6(2): 100-111.

da Gama RM, Guimarćes M, de Abreu LC, \& ArmandoJunior J. 2014. Phytochemical screening and antioxidant activity of ethanol extract of Tithonia diversifolia (Hemsl) A. Gray dry flowers. Asian Pac. J. Trop. Biomed. 4(9): 740-742.

Djunaedy A. 2009. Biopestisida sebagai pengendali organisme pengganggu tanaman (OPT) yang ramah lingkungan. Embryo 6(1): 88-95.

Finney DJ. 1971. Probit Analysis, $3^{\text {rd }}$ ed. Cambridge University Press, Cambridge.

Fouad HA, Faroni LRDA, Tavares WS, Ribeiro RC, Freitas SS, \& Zanuncio JC. 2014. Botanical extracts of plants from the Brazilian Cerrado for the integrated management of Sitotroga cerealella (Lepidoptera: Gelechiidae) in stored grain. J. Stored Prod. Res. 57: 6-11. 
Ibrahim MA, Kainulainen P, Aflatuni A, Tiilikkala K, \& Holopainen JK. 2001. Insecticidal, repellent, antimicrodial activity and phytotoxicity of essential oils: with special reference to limonene and its suitability for control of insect pests. Agri. Food Sci. Finland 10: 243-259.

Isman MB. 2014. Botanical insecticides: a global perspective. In: Biopesticide: State of the Art and the Future Opportunities. pp. 21-30. ACS. Washington, D.C.

Kau CH \& Cheng EY. 2001. Insecticides resistence in Plutella xylostella L. J. Agric. Res. China. 50(4): 80-89.

Kuo YH \& Chen CH. 1998. Sesquiterpenes from the leaves of Tithonia diversifolia. J. Nat. Prod. 61(6): 827-828.

Kolawole AO, Olajuyigbe FM, Ajele JO, \& Adedire JO. 2014. Activity of the antioxidant defense system in a typical bioinsecticide-and synthetic insecticide-treated cowpea storage beetle Callosobruchus maculatus F. (Coleoptera: Chrysomelidae). Int. J. Insect Sci. 6: 99-108.

LeOra Software. 1987. POLO-PC User's Guide. LeOra Software. Petaluma.

Mkenda PA, Mtei K, \& Ndakidemi PA. 2014. Pesticidal efficacy of Tephrosia vogelii and Tithonia diversifolia against field insect pests of common beans [Phaseolus vulgaris L.] within African farming communities. Afr. J. Appl. Agric. Sci. Technol. 2(1): 9-26.

Mkenda PA \& Ndakidemi PA. 2014. Pesticidal efficacy of four botanical pesticides on survival, oviposition and progeny development of bruchid, Callosobruchus maculatus in stored cowpea, Vigna unguiculata. IJPS 3(12): 1504-1523.

Mukasa D, Olila D, Tinzaara W, \& Kagezi GH. 2008. Effects of Tithonia and Phytolacca extracts against the banana weevil, Cosmopolites sordidus (Germar) (Coleoptera: Curculionidae). AJABS 3(1): 24-29.
Mwanauta RW, Mtei KA, \& Ndakidemi PA. 2014. Prospective bioactive compounds from Vernonia amygdalina, Lippia javanica, Dysphania ambrosioides and Tithonia diversifolia in controlling legume insect pests. Agri Sci 5(12): 1129-1139.

Onekutu A, Nwosu LC, \& Abakpa RE. 2015. Comparative efficacy of aqueous extracts of Tithonia diversifolia (Asteraceae) and Vernonia amygdalina (Asteraceae) leaves in the management of Sitophilus zeamais infestation in stored maize. IOSR-JPBS 10(3): 66-70.

Osipitan AA \& Oseyemi AE. 2012. Evaluation of the bio-insecticidal potential of some tropical plant extracts against termites (Termitidae: Isoptera) in Ogun State, Nigeria. J. Entomol. 9: 257-265.

Otusanya O \& Ilori O. 2012. Phytochemical screening and the phytotoxic effects of aqueous extracts of Tithonia diversifolia (Hemsl) A. Gray. Int. J. Biol 4(3): 97-101.

Oyedokun AV, Anikwe JC, Okelana FA, Mokwunye IU, \& Azeez OM. 2011. Pesticidal efficacy of three tropical herbal plants' leaf extracts against Macrotermes bellicosus, an emerging pest of cocoa, Theobroma cacao L. J. Biopestic. 4(2): 131-137.

Pardono. 2011. Potensi Chromolaena odorata dan Tithonia diversifolia sebagai sumber nutrisi bagi tanaman berdasarkan kecepatan dekomposisinya. Agrovigor 4(2): 80-85.

Rodriguez J, Montoya-Lerma J, \& Calle Z. 2015. Effect of Tithonia diversifolia mulch on Atta cephalotes (Hymenoptera: Formicidae) nests. $J$. Insect Sci. 15(32): 1-7.

Rusli R, Arneti, \& Permata SS. 2010. Pengujian ekstrak metanol bunga kipat (Tithonia diversifolia A. Gray) (Asteraceae) untuk mengendalikan Spodoptera exigua Hubner (Lepidoptera: Noctuidae). J. Manggaro 11(1): 25-32.

Sarfraz M \& Keddie BA. 2005. Conserving the efficacy of insecticides against Plutella xylostella (L.) (Lep., Plutellidae). J. Appl. Entomol. 129(3): 149-157. 
Syed TS, Abro GH, \& Ahmed S. 2004. Efficacy of different insecticides against Plutella xylostella under field conditions. Pak. J. Biol. Sci. 7(1): $10-13$.

Utami S, Syaufina L, \& Haneda NF. 2010. Daya racun ekstrak kasar daun bintaro (Cerbera odollam Gaertn.) terhadap larva Spodoptera litura Fabricius. JIPI 15(2): 96-100.

War AR, Paulraj MG, Husain B, Buhroo AA, Ignacimuthu S, \& Sharma HC. 2013. Effect of plant secondary metabolites on legume pod borer, Helicoverpa armigera. J. Pest. Sci. 86(3): 399408.
Wardhana AH \& Diana N. 2014. Aktivitas biolarvasidal ekstrak metanol daun kipahit (Tithonia diversifolia) terhadap larva lalat Chrysomya bezziana. JITV 19(1): 43-51.

Zanetti R, Zanuncio JC, Santos JC, Silva WLP, Ribeiro GT, \& Lemes PG. 2014. An overview of integrated management of leaf-cutting ants (Hymenoptera: Formicidae) in Brazilian forest plantations. Forests 5(3): 439-454. 